\title{
Literárny historik Vladimír Petrík medzi nami
}

\author{
Viera Žemberová (Prešov)
}

\begin{abstract}
Abstrakt
Literárny vedec Vladimír Petrík patril do výraznej generácie povojnových absolventov filologického štúdia na Univerzite Komenského. Prirodzene svoj kontakt s literárnym životom, literatúrou a jej tvorcami začínal ako literárny kritik v polovici minulého storočia, aby podstatnú čast' svojho profesijného pôsobenia v slovenskej literárnej vede spojil s literárnou históriou. Čas aj aktivity jeho generácie prirodzene ustúpili na začiatku milénia mladým kolegom, medzi nimi získal V. Petrík odborný, kolegiálny a ludský rešpekt pre svoju odbornost’ a spôsob, akým sa vyrovnával s vývinom a jeho náročným spoločenským, hodnotovým a personálnym obsahom. Vladimír Barborík a Magdalena Bystrzak sa k osobnosti literárneho historika vrátili, spracovali a doplnili jeho nedokončený rukopis venovaný osobnosti Alexandra Matušku a vývinu slovenskej literárnej vedy v ich vzájomnom prepojení.
\end{abstract}

\section{Kl'účové slová}

literárny vývin; literárny život; literárna história; národná literatúra; generácia; generačný spor; hodnota a význam kritickej reflexie

\section{Abstract}

\section{The Literary Historian Vladimír Petrík Among Us}

Vladimír Petrík belonged to a significant generation of post-war graduates of philological studies at Comenius University. Naturally, he began his contact with literary life, literature and its creators as a literary critic in the middle of the last century, to associate a substantial part of his professional activity in Slovak literary criticism with literary history. The time and activities of his generation naturally retreated at the beginning of the millennium to young colleagues, among them V. Petrík gained professional, collegial and human respect for his expertise and the way he coped with the development and its demanding social, value and personal content. Vladimír Barborik and Magdalena Bystrzak returned to the personality of the literary historian, processed and completed his unfinished manuscript devoted to the personality of Alexander Matuška and the development of Slovak literary criticism in their interconnection.

\section{Key words}

literary development; literary life; literary history; national literature; generation; generation dispute; value and importance of critical reflection 
Predpokladané osobné a profesijné blíženectvo, dômyselný pohyb v literárnovednom výskume a špecifické okolností, ktoré navodí l’udskému životu plynúci čas, lebo ten nestojí, dali vzniknút výnimočnej partnerskej spolupráci Vladimíra Petrika (1929-2017) a Vladimíra Barborika (1965). Generačná pozícia im ponúkla naplno zužitkovanú formu profesijného rozhovoru. Literárny a literárnovedne usmerňovaný rozhovor partnerov v odbore vložil do dejín odboru a kultúrneho vedomia spoločnosti publikácie Hladanie minulého času v roku 2009, to sa Vladimír Barborík pýtal a kládol otázky, a Pohyb k nehybnosti v roku 2018, v nej sa Barborík autorsky emancipuje a stáva sa spoluautorom. Priesečníkom návratov, hladaní a zvažovania toho, čím sa čo aj ako zvýznamňuje, či sa dostáva do iného postavenia v prítomnom čase, v reálnych spoločenských a kultúrnych procesoch, stalo sa pre Vladimíra Petríka a Vladimíra Barboríka minulé storočie, raz jeho druhá polovica, neskôr jeho užšia čast’ - šest’desiate a sedemdesiate roky.

Partnerská, premyslene literárnohistoricky koncipovaná publikácia Pohyb k nehybnosti ${ }^{1}$ má rekonštrukčnú ambíciu podporenú obnovením vývinových pohybov, úsporným výkladom, užitočným a potrebným spresnením a vymedzením podstatných detailov. Ocenit’ treba zvýraznenie prepojenosti mimoliterárnych a literárnych, politických, ekonomických a kultúrnych činitelov napojených na kontinuitu a kauzalitu verifikovatelných spoločenských pohybov od konca pät’desiatych po rané devätdesiate roky minulého storočia. Literárnohistorickou metodikou sprevádzaný kompozičný zámer tvorcov publikácie vytažil zo zaznamenaného pohybu na fotodokumentoch prepojenost̉ a zosúladenie časovej, organizačnej, personálnej a javovej „reality“ pripomenutých desatročí, preto „Súčastou publikácie sú citáty z dobovej kultúrnej a dennej tlače, ako aj z „druhého brehu“ - zo svedeckej biograficko-memoárovej knihy Hany Ponickej Lukavické zápisky. Funkcia citátov je dvojaká informatívna a evokačná"

Historickým a spoločenským východiskom na rekonštrukciu zložitých spoločenských a personálnych pohybov $\mathrm{v}$ šesṫdesiatych rokoch a v sedemdesiatych rokoch sa stala literárnohistoricky, predovšetkým kauzálne a výkladovo koncipovaná čast̉ K problematike slovenského literárneho života po roku 1948, v ktorej sa zdôrazňuje a zvýrazňuje koncept dosahu a predovšetkým presahu ekonomického, politického, inštitucionálneho, personálneho riadenia štátu, účinkovanie moci, jej (do)presahy do kultúrneho, literárneho aj osobného tvorivého života slovenských literátov, literárneho života a literárnej vedy.

Do blokov, ilustračne prevádzaných fotografiami získanými z akcií Kultúrneho života, Slovenského spisovatela, rokovaní spisovatel’ských zjazdov, sú rozložené roky Šesṫdesiate v týchto tematických konceptoch: Roky šest’desiate, Konferencie a zjazdy, Redakcie, Návštevy, Ceny, výlety a kolektívny duch, Tváre. Po tomto desatročí, informáciami, faktograficky a verifikovatel'ne rozširujúcom dostupné učebnicové informácie, nasleduje d’alší, nasledujúcim desatročím zovretý blok pomenovaný Sedemdesiate - normalizačný epilóg a samostatná časṫ venovala autorovi fotografií Anton Šmotlák.

Grafická úprava publikácie naznačuje, že sa vydavatel' prispôsobil vzácnym dobovým fotografiám. Príčinné prepájanie udalostí v jednom aj v po ňom nasledujúcom - svojimi

1 PETRÍK, Vladimír - BARBORÍK, Vladimír: Pohyb k nehybnosti. Literárny život od začiatku 60. do konca 70. rokov objektívom Antona Šmotláka. Bratislava: Literárne informačné centrum, 2018. $244 \mathrm{~s}$.

2 PETRÍK, Vladimír - BARBORÍK, Vladimír: Pohyb k nehybnosti... Op. cit. Predslov, b. č. 
ambíciami tak odlišnom - desatročí vôkol časopisov, vydavatel’stiev, inštitúcií, organizácií, udalostí aj jednotlivcov, pričinením sa „priamočiareho“ výkladu, metódy a spôsobu, ktorými sa v literárnohistorickej, náučnej a vzdelávacej rovine publikácie vyrovnávajú jej tvorcovia s reáliami, zostane ich zámer cenným, ale predovšetkým zrozumitel’ným, verifikovatel’ným a nanajvýš užitočným návratom do nedávnej minulosti. Napokon odstup od historicko-spoločenskej pamäti a sústredenie sa na pohyby a činy v literárnom, kultúrnom a vednom živote obidvoch desatročí potvrdzujú, že bez dôkladného poznania, poučeného porozumenia tomu, čo sa dialo, kto rozhýbaval (ale aj akým spôsobom a výsledkom) koleso ludských príbehov, zostali by v opare nepresností, parciality a reinterpretácií tak podstatné (ne)pohyby, na ktoré reagoval dobový a literárny život, ale nie iba on. Napokon čas prirodzene napreduje, priestor sa modifikuje, generácie utvárané l’udským rodom sa menia aj vd’aka tomu, čo o svojej minulosti vedia, ale ani vtedy by nemali pozabudnút na spoločnú pamät, do ktorej sú po jej tvorcoch uložené ich mená aj tváre.

Prirodzenou a žičlivou letorou vnášal Vladimír Petrík do toho, s čím a s kým sa vyrovnával, predovšetkým systém, pôvodnost’ a prirodzenost', argumenty, rozhladenost’ v dokumentoch a faktoch, dôsledne sa pridŕžal princípu vývinovej následnosti, ale obzvlášt javu hodnota a ňou iniciovaného rešpektu voči poznávacím a umeleckým reáliám, faktom a činovníkom literárnovedného prostredia, kam sám patril po štúdiách od polovice minulého storočia. Pri vymedzovaní osobnosti Vladimíra Petríka, popri ústretovosti a žičlivosti sa musí do typovej triády včlenit aj porozumenie a považovat ho za účinné kritérium pracovných postupov. Petrík ho využíval efektívne, humánne a dôsledne, čo znamená, že vždy, ked' to jeho pamät', literárnohistorický materiál a bádatel’ovo poznanie dovolovali, smeroval bez okolkov k podstate a osobitosti toho, o čom „hovoril“ aj čo zhodnocoval, vždy však dôsledne v súvislostiach so spoločenskými dejinami, (vše)l’udskými dejmi a požiadavkami aktuálnych kultúrnych a vedeckých systémov.

Poznávanie a zbližovanie sa so zámerom, prečo a pre koho bolo vydané rukopisné torzo Vladimíra Petríka Slovenský intelektuál Alexander Matuška $a^{3}$ možno doplnit útržkom z dialógu otca a malého syna z Južnej posty Ladislava Balleka, v ktorom sa dospeloste prihovára mladosti takto - neodišiel, len ho nebudeme stretávat'. A to je v súvislosti s Alexandrom Matuškom obojstranne potrebný rezultát. K Vladimírovi Barboríkovi sa pripojila Magdalena Bystrzak, aby vo finálnej časti publikácie Petrikov Matuška $a^{4}$ ustálila, vysvetlila, zdôvodnila, čím je, ako vznikol a uchoval sa zverejňovaný materiál - „Nedopisanú monografiu doplña výber z Petrikových štúdii a kritických prác, pokrývajúcich celé obdobie Matuškovej tvorivej dráhy"5 - a naznačila tak zámer, kam by autor rukopisného torza, keby mu na to bol dožičený čas, rozvinul do úplnosti členitý literárny, vedecký, osobný a kolegiálny „profil“ aj „portrét" Alexandra Matušku (1910-1975).

Petrikov Matuška vo výklade Magdaleny Bystrzak sa sústredil na empatický prístup k literárnemu historikovi, začína odkazmi na okolnosti genézy a organizovania publikácie,

3 PETRÍK, Vladimír: Slovenský intelektuál Alexander Matuška. Eds. Vladimír Barborík - Magdalena Bystrzak. Bratislava: Literárne informačné centrum, 2019. 153 s.

4 PETRÍK, Vladimír: Slovenský intelektuál Alexander Matuška. Op. cit., čast̉ Petrikov Matuška, s. 143-149.

5 Odkazujeme na text zverejnený na prebale publikácie PETRÍK, Vladimír: Slovenský intelektuál Alexander Matuška. Op. cit. 
objasňuje prítomnost „problémovej a personalizovanej“ tézy ovinutej okolo reálneho času Alexandra Matušku so zámerom Petríkovou optikou vedca a kolegu mat’ azda jediný ciel', ako porozumiet a docenit Matušku v jeho mnohorakosti. Azda práve tento nelahký zámer, ako čelit mýtu a zjednodušovaniu sa pri kompozícii presadil ako „tematický“ pôdorys zosúladený s A. Matuškom.

Bystrzak si položila zásadnú otázku, čím sa literárny historik Petrík stal nezastupitel’ný vo svojej generácii, jej podriadila svoj prístup k hodnote a významu uchovanej matuškovskej témy v Petríkovom literárnohistorickom výskume a v nadväznosti naň na ambíciu editorky, dokázat dostupnými textami prostredníctvom Vladimíra Petríka a za Vladimíra Petríka aj odbornú verejnost’ naznačit, ako sa možno vyrovnat so šírkou záberu (od počiatku po ukončenie pôsobenia v literárnej vede) s nemalým počtom záujmov, sporov, postojov, problémov spojených s osobnostou Alexandra Matušku od pätdesiatych rokov po jeho úmrtie. A tak stále ide o jediné, „Čo teda považoval Petrik za spravodlivé?"“

Sugestívna a súčasne nesmierne náročná otázka, pohlcuje a žiada si odpoved’ na „všetko“, doslova na všetko, čím literárny vedec žil, čím a kým bol, ako konal a zvažoval, o čom a komu vypovedal. Odpoved' na otázku, ktorá sa od osobného roztvorí do dobového a profesijného, do spoločenského a kultúrneho, sa sústredila na vertikálu etiky vedeckej práce, na uplatnenie morálky a intelektuálnej zručnosti v systéme literárnej vedy ako normy na získanie a na hodnotenie toho, čím žilo a žije spoločenstvo, do ktorého sa včlenil Vladimír Petrík a súbežne s ním to, čomu sa venoval.

Po otázke pýtajúcej sa na mieru a koncept spravodlivosti v Petríkovej osobnostnej výbave nasleduje Bystrzakovej verdikt, ním sumarizuje jedinečnost̉ Petríkovho výskumu, ten spočíva v ním aplikovanej výskumnej optike, ktorá je zrejmá aj zo zachovaného rukopisného fragmentu monografie. Literárny historik rešpektuje pramene a personalizovaného autora, teda hodnotí to, čo považuje za „generálne“, vedome „paušálne“ neodsudzuje, miestami psychologizuje (najmä tam, kde píše o trvalom vnútornom založení, temperamente, charaktere, vnútornom posune a podobne). Spolieha sa na vlastné čítanie, vie revidovat už raz povedané, a preto sa po rokoch „znova pozerá na texty“. Týmto získava status nestranného pozorovatel’a, ktorý neuplatňuje jednoznačné videnie sveta. Nepotrebuje autority (citácie v texte mu slúžia predovšetkým na to, aby textovo doložil vlastný výklad). Vd’aka tomu je suverénny - „nefixuje sa na cudzie hodnotenia a zdôvodňuje vlastne" .

Slovenský intelektuál Alexander Matuška, a to editori rukopisu zvýrazňujú, vznikol z toho, na čom Vladimír Petrík pracoval priebežne a nemal možnost' dokončit do tvaru monografie, teda z príspevkov, ktoré príležitostne desatročia pri rozličných príležitostiach a podnetoch venoval Matuškovej tvorbe, osobnosti a činom v literárnej vede, esejistike alebo na podnet prostých l’udských postojov blížiacich ho ku kultúre, o čom precízne napovie a zorientuje edičná poznámka ${ }^{8}$ : „Kniha Slovenský intelektuál Alexander Matuška je okrem jedného textu výberom z časopisecky publikovaných prác, ktoré Vladimír Petrík venoval $9^{9}$ osobnosti a dielu Alexandra

6 PETRÍK, Vladimír: Slovenský intelektuál Alexander Matuška. Op. cit., čast̉ Petríkov Matuška, s. 143.

7 Tamže, s. 143-144.

8 Tamže, čast’ Edičná poznámka, s. 125-139.

9 Tamže, čast’ Petrikov Matuška, s. 143-144. 
Matušku. Súbor vznikol po smrti autora a do tejto podoby ho usporiadali editori. Publikácia bola zostavená a vydaná s dvojakým zámerom, pietnym a poznávacim"10.

Získaný materiál z časopiseckého zázemie textov venovaných Alexandrovi Matuškovi rozčlenil publikáciu do dvoch častí. Expozíciou je štúdia Alexander Matuška ${ }^{11} \mathrm{~s}$ ukážkou Petríkovho rukopisu. Do prvej časti monografie sú zaradené tie Petríkove práce, prostredníctvom ktorých rekonštruuje nejednoznačnú osobnost', tenzijného kultúrneho činovníka, zanieteného presadzovatela svojich aj svojských názorov na vedu, modernost', estetiku v literárnom umení, ale aj na etiku vedeckej práce a jej tvorcu. V tejto časovej a tematickej či až problémovej matuškovskej línii - pozostáva z desiatich samostatných štúdií - sa vráti Vladimír Petrík k Matuškovým výskumným a výkladovým autorským dielňam, k monograficky spracovaným osobnostiam s nadnárodným noetickým a estetickým významom, k Vajanskému, Hronskému a Karlovi Čapkovi; k polemikám, ktoré temperamentne viedol s dobovou literárnou kritikou, k autorskému žánru eseje, etike kritiky a kritika a vrcholí Petríkovým osobným tónom v texte Alexander Matuška - ako som ho poznal ${ }^{12}$.

Druhý kompozičný blok má dva tematické príspevky Slovenská kritika v tridsiatych rokoch a F. X. Šalda ${ }^{13}$ a Dvaja z generácie ${ }^{14}$. Druhou častou publikácie sa editori publikácie sústredili a vlastne vrátili k Petríkovej metóde rozvážne a detailne vypovedat o podstate zložitých profesijných a odborných priesečníkov v literárnohistorickom pohybe vývinu v literatúre a vo vede o literatúre. Ozveny Šaldovej kritickej metódy zachytil Vladimír Petrík na nesúlade medzi A. Matuškom a Jánom Elenom Borom. Petrík zverejní svoj verdikt: „V spore Matuška - Bor má pravdu Matuška“, ale i to, že „Matuška má ambíciu zopakovat'v slovenskom prostredi Šaldov kritický typ. Ideová príbuznost' prerástla tu do príbuznosti typologickej“15 $\mathrm{s}$ rezultátom nadčasovej hodnoty, „Matuškova deviza z tých čias, že kultúra sa robi aj charakterom, poukazuje priamo na Šaldu. V slovenských reláciách zohralo Šaldovo dielo svoju „historickú“ úlohu v tridsiatych rokoch. Ale ako hodnota, ku ktorej sa hlásime a ktorú akceptujeme, môže a bude pôsobit’ inšpirujúco a obrodzujúco $i$ v budúcnosti“"16. Názorový a hodnotový stret medzi Alexandrom Matuškom a Michalom Chorváthom má viacero dotykových miest, začat možno rovnakým mesiacom narodenia, štúdiami na pražskej akademickej pôde, pokračovat odkazom na osobnú povstaleckú skúsenost’ a ukončit v horizontále rovnakým pracoviskom v SAV; Matuška do Ústavu slovenskej literatúry nastúpil na konci pätdesiatych rokov a Michal Chorváth na počiatku nasledujúceho desat̉ročia. Priesečníkom ich odlišného konceptu národnej literatúry, problém tradície a kontinuity, tradičného a moderného sa odohrával postupmi literárnej kritiky.

10 Tamže, čast' Edičná poznámka, s. 125.

11 Tamže, čast' Alexander Matuška, s. 7-16.

12 Tamže, čast' Alexander Matuška - ako som ho poznal, s. 95-100.

13 Tamže, čast' Petrikov Matuška, s. 101-109.

14 Tamže, s. 110-121.

15 Tamže, čast' Slovenská kritika v tridsiatych rokoch a F. X. Šalda, s. 108.

16 Tamže, s. 109. 
Vladimír Petrík začínal medzi literárnymi kritikmi, prirodzeným precizovaním svojej metódy a objektu výskumu vrcholí jeho pôsobenie v literárnej vede aj v nedokončenej monografii venovanej Alexandrovi Matuškovi, na jeho personálnom pozadí aj vývinu slovenskej literatúry a literárnej vedy za viac ako pät desatročí v literárnej histórii. Petríkov hlas je hlas výraznej generácie a osobností v slovenskej vede o literatúre minulého storočia, ktoré svoje posty prirodzene opúštajú, ale Vladimír Petrík v zastúpení svojich editorov naznačuje, že (nevyh)nutne nemusia a nesmú stíchnut.

\section{Literatúra}

PETRÍK, Vladimír - BARBORÍK, Vladimír: Pohyb k nehybnosti. Literárny život od začiatku 60. do konca 70. rokov objektívom Antona Šmotláka. Bratislava: Literárne informačné centrum, 2018. $244 \mathrm{~s}$.

PETRÍK, Vladimír: Slovenský intelektuál Alexander Matuška. Eds. Vladimír Barborík - Magdalena Bystrzak. Bratislava: Literárne informačné centrum, 2019. 153 s.

prof. PhDr. Viera Žemberová, CSc.

Inštitút slovakistiky a mediálnych štúdií

Filozofická fakulta, Prešovská univerzita v Prešove

Ul. 17. novembra 1, 08000 Prešov, Slovensko

viera.zemberova@unipo.sk 